\title{
CHEMICAL AND MICROBIAL STUDIES ON Reaumuria hirtella JAUB and SPASH
}

(Received:29.1.2014)

\author{
By \\ A. E. Abozeed \\ Medicinal and Aromatic Plants Department, Desert Research Center, El-Matarya, Cairo, Egypt
}

\begin{abstract}
The main objectives of the current investigation were to study the chemical constituents as well as the anti-microbial effect of Egypt Reaumuria hirtella growing naturally in the Western Mediterranean Coastal region (Ageba region) in different seasons. Phyto-chemical screening of the plant revealed the presence of sterols, tannins, flavonoid, alkaloids, carbohydrates, sulphates and chlorides. It is clear that the total flavonoids and tannins reached their maximum values $(2.08 \%, 8.63 \%$, respectively) during winter while the total phenolics and alkaloids reached their maximum values $(1.52 \%, 0.38 \%$ respectively) during summer. We also indicated that, glucose, maltose, ribose, arabinose and sucrose are present as free sugars while glucose, ribose, arabinose and rhamnose are present as combined sugars. The amino acid analysis showed that, the plant contains 12 free amino acids and 15 protein amino acids. In addition, the chemical constants of lipids of Reaumuria hirtella were determined. The unsaponifiable matter of the lipid contains 10 hydrocarbons and $\beta$-sitosterol as well as the fatty acid content showed that, stearic acid was found as major content followed by nine fatty acids. Preliminary screening of the anti -microbial activity of different successive extracts (petroleum ether, ether, chloroform, ethyl acetate, acetone, ethyl alcohol $70 \%$ and water) of $R$. Hirtella against some pathogenic microorganisms respectively three species of bacteria and two species of fungi were performed using the method described by Zahra (1990). All extracts were not effective in inhibiting the growth of the organisms except with the high concentration $(2000 \mathrm{ppm})$ of ethyl acetate. From these data, it is suggested that under stress Reaumuria hirtella plants tend to accumulate secondary metabolic products, which may be a part of adaptation to unfavourable conditions.
\end{abstract}

Key words: alkaloids, chemical, flavonoids, microbial, phyto-chemical screening, tannins and phenolic compounds.

\section{INTRODUCTION}

Reaumuria hirtella belongs to family Tamaricaceae which is a limited family, it contains only 5 genera and 79 species distributed all over the world. The family is native to dry areas, many grown on saline soils, tolerating up to $15,000 \mathrm{ppm}$ soluble salt and can also tolerate alkaline conditions. Many plants of this family are used as medicinal plants (Mabbereley, 2008). Genus Reaumuria contains four species (Reaumuria hirtella, Reaumuria mucronata, Reaumuria vermiculata and Reaumuria alternifolia). Stems and often also the leaves of Reaumuria hirtella are covered during daytime by salt crystals, which absorb water during the night when the shrublet is bading in water drops. Flowers white or pink with purple anthers (Tackholm, 1974).

Yoshida et al. (1991) investigated the tannins of the leaf extract of Reaumuria hirtella and found that, it contains two new monomeric hydrolysable tannins, remurin A (12), remurin A (13) and a new dimer hirtellin A (7). Four new dimeric hydrolysable tannins, hirtellins C, D, E, $\mathrm{F}$ besides previously hirtellins $\mathrm{A}$ and $\mathrm{B}$ have been isolated from the leaf extract of Reaumuria hirtella (Yoshida et al., 1993). New dimeric, trimeric and tetrameric ellagitannins, hirtellin T2 (1), hirtellin T3 (25), hirtellin T (5), hirtellin G (1) and hirtellin Q (6) have been isolated from the leaf extract of Reaumuria hirtella (Ahmed $e t$ al., $1994 \mathrm{a \& b}$ ). Nawwar et al. (2012) isolated three ellagitannins and one disulphated flavonol from the aerial parts of Reaumuria vermiculata.

The medicinal values of certain members of Reaumuria which have been in literature, stimulated us to carry out the present study.

\section{MATERIALS AND METHODS}

The aerial parts of Reaumuria hirtella Jaub. 
\& Spach. were collected during winter, spring, summer and autumn seasons of 2013 from Ageba region (Northern Coastal Region Egypt). The collected plants were cleaned, dried in an oven at $60{ }^{\circ} \mathrm{C}$ for 48 hours, ground to fine powder and presented for the following chemical investigation.

\subsection{Preliminary phytochemical screening \\ 2.1.1. Steam distillation}

About $50 \mathrm{~g}$ of fresh plant material were extracted by steam distillation according to British Pharmacopoeia (1980) method for volatile oil content.

\subsubsection{Screening of the active constituents}

About $50 \mathrm{~g}$ of air dried powdered plant material were refluxed with about $50 \mathrm{ml}$ of $80 \%$ ethyl alcohol for 6 hours, then filtered. The residual powder was then washed several times with hot alcohol. The combined alcohol filtrates were concentrated under reduced pressure at $50^{\circ} \mathrm{C}$, then used for determination of tannins and saponins (Balbaa 1986), sterols and terpens (Balbaa et al., 1981), flavonoids (Wall et al. 1954), alkaloids (Woo et al., 1977), carbohydrates and/or glycosides (Harper, 1975), chlorides and sulphates (A.O.A.C. 1970), coumarins and anthraquinones (Fransworth, 1966).

\subsection{Extraction using organic solvents}

\subsubsection{Successive extraction technique}

Powdered air-dried plant material were subjected to extraction with successive selected organic solvents using soxhlet apparatus, in order of increasing polarity including petroleum ether (B.p. $40-60{ }^{\circ} \mathrm{C}$ ), diethyl ether, chloroform, acetone , ethyl acetate, 96\%, ethyl alcohol and $70 \%$ ethyl alcohol. The obtained residue from each solvent was dried and weighed.

\subsubsection{Selective extraction technique}

The powdered air dried plant material were extracted completely once using soxhlet apparatus with the same solvents. The obtained residue from each solvent was calculated by weighing after complete dryness.

\subsection{Determination of constants and other constituents}

Water content was estimated according to the method described by Rowell (1994), the total, soluble and insoluble carbohydrates were determined according to Chaplin and Kennedy (1994). The total nitrogen and protein contents were determined according to James (1995) and the total lipids were determined according to Christie (1982). The total ash content, acid and water insoluble ash and the crude fiber contents were determined according to Askar and Treptow (1993).

\subsection{Determination of active constituents}

Total flavonoids (Karawya and Aboutable, 1982), total alkaloids Balbaa (1986) and Woo et al. (1977), total phenolics (Pulido et al. 2000) and total tannins (Makkar and Googchild 1996). were determined.

\subsection{Investigation of carbohydrates}

Free and combined sugars were determined during winter season using paper chromatography (Chaplin and Kennedy, 1994).

\subsection{Identification and fractionation of free and protein amino acids}

The free and hydrolyzed protein-amino acids were determined during winter using amino acid analyzer according to the method described by Pellet and Young (1980).

\subsection{Determination of crude lipids}

The lipids were extracted from the powdered plant collected at winter with petroleum ether (B.P. $\left.40-60^{\circ} \mathrm{C}\right)$ : ether $(1: 1 \mathrm{v} / \mathrm{v})$ for 24 hours using soxhlet apparatus. The lipids were obtained by distilling off the solvent. The last traces of the solvents were removed by heating the liquid sample in vacuum oven a $50{ }^{\circ} \mathrm{C}$ to constant weight.

\subsubsection{The fundamental chemical properties}

Acid value (A. V.), Iodine value (I. V.), ester value (E. V.) and saponification value (S. V.) were determined according to Mohamed and Amer (1965).

\subsubsection{Investigation of fatty acids and unsaponifiable matter}

The extracted lipids of Reaumuria hirtella were saponified and purified according to British Pharmacopoeia (1980). The unsaponifiable fraction was removed from the soapy solution by shaken in a separating funnel for several times with fresh portions of peroxide-free ether until complete extraction was obtained.

The soapy solution was converted into the corresponding free fatty acids by using of $2.5 \%$ sulphuric acid. When the acid was completely liberated, they were collected by ether extraction. The ether extracted was washed several times with distilled water until free from acids, dried over anhydrous $\mathrm{Na}_{2} \mathrm{SO}_{4}$, then filtered and the ether was removed by distillation. The last traces of ether were removed under vacuum at $60^{\circ} \mathrm{C}$, and then cooled in a desiccator.

\subsubsection{GLC of fatty acids}

The extracted fatty acids and the standards were converted to the corresponding methyl 
esters using ethereal solution of diazomethane (Farag et al., 1986). The methyl ester of the fatty acids was analyzed with a GCV. Pye-Unicam gas chromatography apparatus. The fraction of fatty acid methyl esters were conducted using a coiled glass column $(\mathbf{1 5 0} \mathbf{m} 4 \mathbf{m m})$, packed with diatomite C (100-120 mesh) and coated with $10 \%$ polyethylene glycol.

The column oven temperature was programmed at $10{ }^{\circ} \mathrm{C} /$ minute for $100,200^{\circ} \mathrm{C}$, then isothermally at $200{ }^{\circ} \mathrm{C}$ for 15 minutes with nitrogen at $30 \mathrm{ml} /$ minutes. Peak identification was performed by comparing the relative retention time of each compound with those of standard material. The relative proportion of each individual compound was estimated as the ratio of the partial areas of the total area as mentioned by Fryer et al. (1960), Nelson et al. (1969), Farag et al., (1986) and Khalil (1987).

\subsubsection{GLC of unsaponifiable matter}

The relative percentage of each unsaponifiable compound was determined using triangulation method according to Nelson et al. (1969). The results of Itoh et al. (1973) and Farag et al. (1986) were used as a guide to characterize some of the unknown compounds.

\subsection{Anti-microbial activity}

The effect of different extracts of Reaumuria hirtella on the growth of some micro-organisms (bacteria and fungi) was studied by a method described by Zahra (1990).

\section{RESULTS AND DISCUSSION}

\subsection{Preliminary phytochemical screening}

The preliminary phytochemical screening of Reaumuria hirtella extract showed that, it contains sterols, tannins, alkaloids, flavonoids, carbohydrates and / or glycosides, sulphates and chlorides. Neither volatile oil, saponins, coumarins nor anthraquinones were detected as represented in Table (1).

Table (1): Preliminary phytochemical screening of $R$. hirtella.

\begin{tabular}{|l|c|}
\hline Test & Result \\
\hline Volatile oil & - \\
\hline Sterols & + \\
\hline Tannins & + \\
\hline Alkaloids & + \\
\hline Saponins & - \\
\hline Flavonoids & + \\
\hline Carbohydrates and/or glycosides & + \\
\hline Sulphates and chlorides & + \\
\hline Coumarins & - \\
\hline Anthraquinones & - \\
\hline
\end{tabular}

\subsection{Extraction using organic solvents}

\subsubsection{Successive extraction}

Data presented in Table (2) showed that ethyl alcohol $70 \%$ extract was the highest value (4.89\%), followed by ethyl alcohol 96\% extract. The minimum value of residues was that of chloroform extract $(0.25 \%)$.

\subsubsection{Selective extraction}

Data presented in Table (2) showed that, ethyl alcohol $70 \%$ had the highest value $(12.08 \%)$ while petroleum ether extract had the lowest value (1.02\%).

\subsection{Constants and constituents}

Table (3) showed that, the moisture content of Reaumuria hirtella reached its maximum value $(43.28 \%)$ during winter and its minimum value $(30.26 \%)$ during the summer. The decrease of water content in the summer may be due to the increase in the rate of transpiration of the plant and evaporation accompanied with increasing of wind velocity and temperature (Jain , 1997). The ash content of Reaumuria hirtella plant reached its maximum value (12.20 $\%)$ during summer, while its minimum value $(10.14 \%)$ during winter season. This may be attributed to the increase in total ion accumulation because of increasing soil moisture stress during summer. This agrees with the findings of Larcher (1995), Al-Owaimer et al. (2008) and Ahmed and Emam. (2009). Water soluble ash reached its maximum value $(7.82 \%)$ during autumn, while acid insoluble ash reached its maximum value $(13.50 \%)$ during the summer season.

The percentages of total nitrogen and total protein reached their maximum values $(3.50 \%$ and $21.86 \%$, respectively) during winter and their minimum values $(1.25 \%$ and $7.81 \%$, respectively) during the summer season. This may be due to the increase in the metabolic rate of the plant as a result of high water resources of the soil during winter than that during the dry period. Aganga et al. (2003) reported that, Atriplex nummularia contains high concentrations of nitrogen in winter as compared to summer when it has high concentration of sodium.

The total lipid content of Reaumuria hirtella reached its maximum value $(4.06 \%)$ during winter and its minimum value $(1.87 \%)$ during summer. This may be due to the increase in metabolic rates of Reaumuria hirtella during winter which leads to an increase in carbohydrate content, which is converted to lipid by oxidation reaction. 
Table (2): Percentage of residues of Reaumuria hirtella using successive and selective extraction techniques.

\begin{tabular}{|l|c|c|c|c|c|c|c|}
\hline \multirow{2}{*}{ Extraction } & \multicolumn{7}{|c|}{ Solvents } \\
\cline { 2 - 8 } & $\begin{array}{c}\text { Petroleum } \\
\text { ether }\end{array}$ & Ether & Chloroform & Acetone & $\begin{array}{c}\text { Ethyl } \\
\text { acetate }\end{array}$ & $\begin{array}{c}\text { Ethyl } \\
\text { alcohol }\end{array}$ & $\begin{array}{l}\text { Ethyl } \\
\text { alcohol 70\% }\end{array}$ \\
\hline Successive & 1.02 & 1.18 & 0.25 & 0.86 & 1.98 & 2.28 & 4.89 \\
\hline Selective & 1.02 & 4.12 & 2.81 & 7.28 & 9.92 & 9.22 & 12.08 \\
\hline
\end{tabular}

There was a tendency to a gradual decline in total carbohydrates from winter to summer samples, where the percentage of the total carbohydrate content reached its maximum value $(26.62 \%)$ during winter, while its minimum value $(22.78 \%)$ during the summer season. AboKassem et al. (2002) reported that, high salt concentration can result in osmotic adjustment by regulating the accumulation of solutes especially sugars and proteins. Crude fiber content of Reaumuria hirtella reached its maximum value of $(38.00 \%)$ in winter, while its minimum value $(20.98 \%)$ was recorded in autumn season as shown in Table (3).
1997).

The results show that the presence of total phenolics reached its maximum value $(1.52 \%)$ during summer, while its minimum value $(0.81 \%)$ during winter. This may be due to increase activity of esterase and peroxidase enzymes which are responsible for the oxidation of phenolic compounds in plant tissues.

Also, the percentages of total alkaloids reached their maximum value $(0.38 \%)$ during summer and their minimum value $(0.18 \%)$ during autumn. This agrees with the findings of El-Lamey (2005), who reported that there was a tendency of some medicinal plants to

Table (3): Mean values of constants and constituents of the studied plant in different seasons.

\begin{tabular}{|l|c|c|c|c|}
\hline Constants and constituents & Winter & Spring & Summer & Autumn \\
\hline Moisture content \% & 43.28 & 41.32 & 30.26 & 36.82 \\
\hline Ash content \% & 10.14 & 10.30 & 12.20 & 11.18 \\
\hline Water-soluble ash \% & 6.25 & 5.36 & 4.28 & 7.82 \\
\hline Acid-insoluble ash\% & 12.06 & 11.86 & 13.50 & 12.60 \\
\hline Total nitrogen content mg/g dry wt. & 3.50 & 2.72 & 1.25 & 1.89 \\
\hline Total protein content mg/g dry wt. & 21.86 & 16.94 & 7.81 & 11.77 \\
\hline Total lipid content \% & 4.06 & 3.40 & 1.87 & 2.58 \\
\hline Soluble carbohydrates content mg/g dry wt. & 11.82 & 13.69 & 18.80 & 17.60 \\
\hline insoluble carbohydrates content $\mathbf{m g} / \mathrm{g}$ dry wt. & 14.80 & 11.31 & 3.98 & 5.10 \\
\hline Total carbohydrates mg/g dry wt. & 26.62 & 25.30 & 22.78 & 23.70 \\
\hline
\end{tabular}

\subsection{Active constituents}

Total flavonoids, total phenolics, total alkaloids and total tannins contents are showen in Table (4). The percentage of flavonoids reached its maximum value $(2.08 \%)$ during winter and its minimum value $(1.58 \%)$ during summer season. Flavonoids and tannins are phenolic compounds and plant phenolics are a major group of compounds that act as primary antioxidants or free radical scavengers (Polterait, accumulate alkaloids by stress, where the accumulation of alkaloids was significantly increased in dry seasons.

On the other hand, the highest content of tannins $(8.63 \%)$ was detected during winter season and the lowest percentage $(7.13 \%)$ during autumn season. The high percentage of tannins in Reaumuria hirtella may encourage their probable use in diarrhea, piles, as well as tanning (Ghazanfer, 1994).

Table (4): Percentages of the active constituents of $R$. hirtella in different seasons during the period of study (2013).

\begin{tabular}{|l|c|c|c|c|}
\hline Item \% & Winter & Spring & Summer & Autumn \\
\hline Total flavonoids & 2.08 & 2.02 & 1.58 & 1.62 \\
\hline Total phenolics & $\mathbf{0 . 8 1}$ & $\mathbf{0 . 8 8}$ & 1.52 & 1.48 \\
\hline Total alkaloids & $\mathbf{0 . 3 2}$ & $\mathbf{0 . 3 0}$ & $\mathbf{0 . 3 8}$ & $\mathbf{0 . 1 8}$ \\
\hline Total tannins & $\mathbf{8 . 6 3}$ & 8.16 & 7.52 & 7.13 \\
\hline
\end{tabular}


3.5. Identification of free and combined sugars

Data shown in Table (5) illustrate the result of investigation of free and combined sugars of Reaumuria hirtella which revealed the presence of glucose, maltose, ribose, arabinose and sucrose as free sugars but glucose, ribose, arabinose and rhamnose were present as combined sugars.

Table (5): Free and combined sugars of Reaumuria hirtela.

\begin{tabular}{|l|c|c|}
\hline Sugar & $\begin{array}{c}\text { Free } \\
\text { sugar }\end{array}$ & $\begin{array}{c}\text { Combined } \\
\text { sugar }\end{array}$ \\
\hline Glucose & + & + \\
\hline Maltose & + & - \\
\hline Ribose & + & + \\
\hline Arabinose & + & + \\
\hline Sucrose & + & - \\
\hline Rhamnose & - & + \\
\hline Raffinose & - & - \\
\hline
\end{tabular}

\subsection{Free and protein amino acid contents of} R.hirtella

The investigation of the free and hydrolyzed protein amino acids was achieved using amino acid analyzer, where each component was calculated and presented in Table (6), twelve free amino acids were presented in Reaumuria hirtella. Proline had the highest concentration $(0.12 \mathrm{mg} / 100 \mathrm{gm}$ protein) while tyrosine had the lowest value $(0.0026 \mathrm{mg} / 100 \mathrm{gm}$ protein $)$. The obtained results also revealed that, the detected protein amino acids present in Reaumuria hirtella were 15 amino acids, where aspartic acid, glutamic acid and serine represent the highest concentrations of the separated protein amino acids.

\subsection{Lipid content}

3.7.1. Fundamental chemical constants of R.hirtella

The fundamental chemical constant of the extracted lipids of Reaumuria hirtella are presented in Table (7). The acid value reached the value of 76.24 , the ester value was 826.54 , the saponification value was 902.68 and the iodine value was 23.08 .

Table (7): Acid, iodine, esterification and saponification values of lipids of Reaumuria hirtella.

\begin{tabular}{|l|c|}
\hline \multicolumn{1}{|c|}{ constant } & Value \\
\hline Acid value & $\mathbf{7 6 . 2 4}$ \\
\hline Esterification value & $\mathbf{8 2 6 . 5 4}$ \\
\hline Saponification value & $\mathbf{9 0 2 . 6 8}$ \\
\hline Iodine value & $\mathbf{2 3 . 0 8}$ \\
\hline
\end{tabular}

\subsubsection{Investigation of Unsaponifiable matter fraction}

The unsaponifiable matter content (hydrocarbons and sterols) of Reaumuria hirtella was determined using GLC technique, where the relative of each component was calculated and tabulated in Table (8). The obtained results indicated that, Reaumuria hirtella contained n-octadecane, n-eicosane, n-docosane, ntricosane, n-tetracosane, n-pentacosane, nhexacosane, n-octacosane, n-tricontane, ndotriacontane and $\beta$-sitosterol, while $\mathrm{n}$ octacosane had the highest concentration followed by $n$-hexacosane.

Table (6): Free and protein amino acids of Reaumuria hirtella using amino acid analyzer.

\begin{tabular}{|c|c|c|c|}
\hline Amino acid & R.t. & $\begin{array}{c}\text { Free amino acid } \\
(\mathbf{m g} / \mathbf{1 0 0} \text { gm protein })\end{array}$ & $\begin{array}{c}\text { Protein amino acid } \\
(\mathbf{m g} / \mathbf{1 0 0} \text { gm protein })\end{array}$ \\
\hline Aspartic acid & 11.34 & $\mathbf{0 . 0 0 8 2}$ & $\mathbf{0 . 2 0 6 8}$ \\
\hline Threonine & 14.51 & - & $\mathbf{0 . 0 3 8 7}$ \\
\hline Serine & 15.77 & $\mathbf{0 . 0 1 5 2}$ & $\mathbf{0 . 0 9 7 2}$ \\
\hline Glutamic acid & 17.62 & $\mathbf{0 . 0 0 4 4}$ & $\mathbf{0 . 1 2 9 5}$ \\
\hline Proline & $\mathbf{2 0 . 4 3}$ & $\mathbf{0 . 1 2 0 0}$ & $\mathbf{0 . 0 5 4 6}$ \\
\hline Glycine & $\mathbf{2 4 . 4 6}$ & $\mathbf{0 . 0 1 2 2}$ & $\mathbf{0 . 0 7 3 2}$ \\
\hline Alanine & $\mathbf{2 7 . 4 8}$ & $\mathbf{0 . 0 1 1 8}$ & $\mathbf{0 . 0 9 6 8}$ \\
\hline Valine & $\mathbf{3 2 . 7 5}$ & $\mathbf{0 . 0 0 5 8}$ & $\mathbf{0 . 0 3 3 5}$ \\
\hline Isoleucine & 44.38 & $\mathbf{0 . 0 0 4 2}$ & $\mathbf{0 . 0 2 8 6}$ \\
\hline Leucine & 45.65 & $\mathbf{0 . 0 0 2 8}$ & $\mathbf{0 . 0 1 6 9}$ \\
\hline Tyrosine & 49.20 & $\mathbf{0 . 0 0 2 6}$ & $\mathbf{0 . 0 7 8 7}$ \\
\hline Phenyl alanine & $\mathbf{5 1 . 6 9}$ & $\mathbf{0 . 0 0 8 2}$ & $\mathbf{0 . 0 3 2 9}$ \\
\hline Histidine & $\mathbf{5 8 . 1 4}$ & $\mathbf{0 . 0 1 5 8}$ & $\mathbf{0 . 0 2 7 8}$ \\
\hline Lysine & 62.50 & - & $\mathbf{0 . 0 4 8 6}$ \\
\hline Argenine & 67.60 & - & \\
\hline
\end{tabular}

Rt : Retention time 
Table (8): Gas liquid chromatography of hydrocarbons and sterols of Reaumuria hirtella.

\begin{tabular}{|l|c|c|c|}
\hline \multicolumn{1}{|c|}{ compounds } & $\begin{array}{c}\text { Retention } \\
\text { time }\end{array}$ & $\begin{array}{c}\text { Number of } \\
\text { carbon atom }\end{array}$ & $\begin{array}{c}\text { Relative } \\
\text { conc. }\end{array}$ \\
\hline Unknown & $\mathbf{1 2 . 9 2 0}$ & - & $\mathbf{0 . 1 2 9}$ \\
\hline n-Octadecane & 14.117 & 18 & 0.152 \\
\hline n-Eicosane & 16.480 & 20 & 0.157 \\
\hline Unknown & 17.483 & - & $\mathbf{0 . 1 0 2}$ \\
\hline n-Docosane & 18.650 & 22 & $\mathbf{2 . 8 0 6}$ \\
\hline n-Tricosane & 19.230 & 23 & $\mathbf{2 . 0 0 8}$ \\
\hline n-Tetracosane & 20.400 & 24 & $\mathbf{5 . 6 5 2}$ \\
\hline n-Pentacosane & 21.418 & 25 & 1.920 \\
\hline n-Hexacosane & 22.283 & 26 & $\mathbf{8 . 7 2 3}$ \\
\hline n-Octacosane & 24.133 & 28 & 12.308 \\
\hline Unknown & 25.332 & - & 3.812 \\
\hline n-Tricontane & 26.800 & 30 & 5.312 \\
\hline n-Dotriacontane & 28.410 & 32 & 7.123 \\
\hline Unknown & 30.900 & - & 1.128 \\
\hline Unknown & 33.816 & - & 0.672 \\
\hline$\beta$-Sitosterol & 43.800 & 27 & 8.325 \\
\hline
\end{tabular}

\subsubsection{Investigation of saponifiable matter fraction}

Relative percentage of each component was calculated and tabulated in Table (9). The obtained result revealed that, the saturated fatty acid (stearic) represented the highest percentage of fatty acids (17.502\%) while the lowest one was the saturated fatty acid (pelargonic) which had the value of $(0.086 \%)$. aureus) and fungi (Candida albicans and Fusarium oxysporum) are shown in Table (10). The diameters of growth zone of fungi were measured whereas the total number of colonies of bacteria were counted. It can be concluded that, all the used extracts did not possess any antimicrobial activity except for the high concentration of ethyl acetate (2000 ppm) which had some effect on the three types of bacteria beside Fusarium oxysporum.

Table (9): Gas liquid chromatography of fatty acids of Reaumuria hirtella.

\begin{tabular}{|l|c|c|c|}
\hline Name of fatty acids & Retention time & No. of carbon atom & Relative conc. \\
\hline Unknown & 5.384 & - & 0.120 \\
\hline Caprylic acid & 5.820 & 8.0 & 0.262 \\
\hline Pelargonic acid & 6.717 & 9.0 & 0.086 \\
\hline Capric acid & 9.717 & 10.0 & 0.482 \\
\hline Unknown & 10.216 & - & 0.208 \\
\hline Lauric acid & 11.083 & 12.0 & 0.826 \\
\hline Myristic acid & 13.683 & 14.0 & 2.012 \\
\hline Pentadecyclic acid & 15.100 & 15.0 & 0.828 \\
\hline Palmitic acid & 16.200 & 16.0 & 11.270 \\
\hline Unknown & 18.600 & - & 5.216 \\
\hline Stearic acid & 20.583 & 18.0 & 17.502 \\
\hline Linoleic acid & 21.560 & 18.2 & 8.813 \\
\hline Unknown & 24.800 & - & 9.118 \\
\hline
\end{tabular}

\subsection{Anti-microbial activity}

The obtained data of the effect of different successive extracts, petroleum ether, chloroform, ethyl acetate, acetone, ethyl alcohol $70 \%$ and water on the inhibition of growth of some microorganisms such as bacteria (Proteus vulgaris, Proteus mirabilis and Staphylococcus
The present study provides a scientific basis of the use of these plant extracts in traditional health care system. Detailed work by using different methods will be the aim of further investigation. Also, the present study will be helpful for further research in the field of pharmaceuticals. 
Table (10): Effect of different successive extracts of Reaumuria hirtella on growth of some bacterial strains and fungi.

\begin{tabular}{|c|c|c|c|c|c|c|}
\hline \multirow[t]{2}{*}{ Plant extract } & \multirow{2}{*}{$\begin{array}{c}\text { Extract } \\
\text { conc. } \\
\text { (ppm) }\end{array}$} & \multicolumn{3}{|c|}{ Bacteria } & \multicolumn{2}{|c|}{ Fungi } \\
\hline & & $\begin{array}{l}\text { Proteus } \\
\text { vulgaris }\end{array}$ & $\begin{array}{l}\text { Proteus } \\
\text { mirabilis }\end{array}$ & $\begin{array}{c}\text { Staphylococcus } \\
\text { aureus }\end{array}$ & $\begin{array}{l}\text { Candida } \\
\text { albicans }\end{array}$ & $\begin{array}{l}\text { Fusarium } \\
\text { oxysporum }\end{array}$ \\
\hline \multirow{4}{*}{$\begin{array}{l}\text { Petroleum } \\
\text { ether }\end{array}$} & 250 & -ve & -ve & -ve & -ve & -ve \\
\hline & 500 & -ve & -ve & -ve & -ve & -ve \\
\hline & 1000 & -ve & -ve & -ve & -ve & -ve \\
\hline & 2000 & -ve & -ve & -ve & -ve & -ve \\
\hline \multirow[t]{4}{*}{ Ether } & 250 & -ve & -ve & -ve & -ve & -ve \\
\hline & 500 & -ve & -ve & -ve & -ve & -ve \\
\hline & 1000 & -ve & -ve & -ve & -ve & -ve \\
\hline & 2000 & -ve & -ve & -ve & -ve & -ve \\
\hline \multirow[t]{4}{*}{ Chloroform } & 250 & -ve & -ve & -ve & -ve & -ve \\
\hline & 500 & -ve & -ve & -ve & -ve & -ve \\
\hline & 1000 & -ve & -ve & -ve & -ve & -ve \\
\hline & 2000 & -ve & -ve & -ve & -ve & -ve \\
\hline \multirow[t]{4}{*}{ Ethyl acetate } & 250 & -ve & -ve & -ve & -ve & -ve \\
\hline & 500 & -ve & -ve & -ve & -ve & -ve \\
\hline & 1000 & -ve & -ve & -ve & -ve & -ve \\
\hline & 2000 & $+v e$ & + ve & $+v e$ & -ve & $+v e$ \\
\hline \multirow[t]{4}{*}{ Acetone } & 250 & -ve & -ve & -ve & -ve & -ve \\
\hline & 500 & -ve & -ve & -ve & -ve & -ve \\
\hline & 1000 & -ve & -ve & -ve & -ve & -ve \\
\hline & 2000 & -ve & -ve & -ve & -ve & -ve \\
\hline \multirow{4}{*}{$\begin{array}{l}\text { Ethyl alcohol } \\
70 \%\end{array}$} & 250 & -ve & -ve & -ve & -ve & -ve \\
\hline & 500 & -ve & -ve & -ve & -ve & -ve \\
\hline & 1000 & -ve & -ve & -ve & -ve & -ve \\
\hline & 2000 & -ve & -ve & -ve & -ve & -ve \\
\hline \multirow[t]{2}{*}{ Water } & 250 & -ve & -ve & -ve & -ve & -ve \\
\hline & 500 & -ve & -ve & -ve & -ve & -ve \\
\hline
\end{tabular}




\section{REFERENCES}

Abo-Kassem E.M., Kasim W.A. and Hamada, E.A.M. (2002). Effect of three potassium salts and metabolites and enzyme activities in Raphanus sativus L. Proc. $2^{\text {nd }}$. Int. Conf. Biol. Sci., (ICBS) Fac. Sci., Tanta Univ., Egypt 409-420.,

Aganga A.A., Mthetho J.K. and Tshwenyane S. (2003). Atriplex nummularia (old man salt bush). A potential forage crop for arid regions of Botswana. P. J. of Nutr., 2 (2): 72-75.

Ahmed F.A. and Emam Sh. Sh. (2009). Chemical constituents of Senniella spongiosa (F. Muell.). Bull. Fac. Agric., Cairo Univ., Egypt, 378-387.

Ahmed A.F., Memon M.U., Yoshida T. and Okuda T. (1994 a). Tannins of Tamaricaceous plants VI. Four new trimeric hydrolysable tannins from Reaumuria hirtella and Tamarix pakistanica. G.P. Bull., 42: 254-264.

Ahmed A.F., Yoshida, T. and Okuda, T. (1994 b). Tannins of Tamaricaceous plants V. New dimeric, trimeric and tetradimeric ellagitannins from Reaumuria hirtella. Chem. Pharm. Bull., 42: 246-253.

Al-Owaimer A.N., Zahran S.M. and El-Bssam B.A. (2008). Effect of feeding some types of Atriplex spp. in complete diet on growth performance and digestibility of growing lambs. Res. Bult., No. (161), Food Sci. \& Agric. Res. Center. King Saud Univ., Saudi Arabia, P. 5-19.

Askar A. and Treptow H. (1993). In" Quality Assurance". Springer-Verlag Berlin Heidlberg, Printed in Germany, 238 pp .

Association of Official Agricultural Chemists (A.O.A.C.) (1970). Official Methods of Analysis, $11^{\text {th }}$ Ed. The A.O.A.C., Washington D.C., U.S.A.

Balbba S.I. (1986). Chemistry of crude drugs laboratory manual. Faculty of Pharmacy, Cairo Univ., Egypt. 195 pp.

Balbba S.I., Hilal S.H. and Zaki A.Y. (1981). Medicinal plant constituents, $3^{\text {rd }}$ Ed. General Organization for Univ .Books, Cairo, Egypt. 644 pp.

British Pharmacopoeia (B.P.) (1980). Volume II: Published on the recombination of the Medicinal commission. Printed in England for Majesty's Stationary Office at the University Press, Cambridge, U.K., PP.561.
Chaplin M.F. and Kennedy J.F. (1994). Carbohydrates Analysis- A practical Approach. Oxford Univ. Press, Oxford, New York, Tokyo. $2^{\text {nd }}$ Ed. 324 pp.

Chrisitie .W.W. (1982). Lipid Analysis. $2^{\text {nd }}$ Edition, Pergamon Press, 207 pp.

El-Lamey T.A. (2005). The effect of some ecological factors on the chemical compounds in some xerophytes for enhancing their use. Ph.D. Thesis, Department of Biological and Physical Science. Institute of Environmental Studies and Research, Ain Shams Univ, Egypt, 216 pp.

Farag R.S., Ahmed A.C., Rashed S.E. and Ewies M.A. (1986). Unsaponifiable matter of six pollens collected by honeybees in Egypt. J. Agric. Res. 19 (4): 52-58.

Fransworth N.R. (1966). Biological and phytochemical screening of plants. J. Pharm. Sci., 55: 225-276.

Fryer F.H., Ormand, W.L. and Crimp, G.M. (1960). Triglyceride elution by gas chromatography. AOCS, 37:589-590.

Ghazanfar S.A. (1994). In "Hand Book of Arabian Medicinal Plants". CRC Press, Boka Raton, Ann Arbor, London. Tokyo. 120-127.

Harper H. A. (1975). In "Review of Physiological Chemistry". $15^{\text {th }}$ Ed. Long Medicinal Publication, Los Angles, California, USA pp. 570.

Itoh T., Tamura T. and Matsumoto T. (1973). Sterol composition of 19 vegetable oils. JAOCS, 50: 12-125.

Jain V.K. (1997). In "Fundamentals of Plant Physiology". $5^{\text {th }}$ Ed., published by $\mathrm{S}$. Chand Company Ltd.,(pub.) Ram Nagar, New Delhi. India137 pp.

James C.S. (1995). In "Analytical Chemistry of Foods". Blackie academic and professional publisher, an Imperin of Chapman and Hall, p 178.

Karawya M.S. and Aboutable E.A. (1982). Phytoconstituents of Tabernaemontana cormaria Jac. Q. Willed and Dichotoma roxii B.grwoing in Egypt. Part IV: The flavonoid. Bulletin of Faculty of Pharma, Cairo Univ., 21(1):41-49.

Khalil M.F. (1987). Evaluation of Butter Fat and Virgin Oil Quality and Integrity. Ph.D. Thesis, Fac. Agric., Cairo Univ. Egypt.

Larcher W. (1995). In "Physiological Plant 
Ecology". Springer Verlage, Berlin Heidelberg, Germany, 506 pp.

Mabberley D.J. (2008). Mabberley plant - Book. Aportable Dictionary of Plants, Their Classification and Uses, $3^{\text {rd }}$ ed. Cambridge: Cambridge University Press.

Makkar H.P.S and Googchild A.V. (1996). Quantification of Tannins: A Laboratory Manual. International center of Agricultural Research in the Dry Areas, Aleppo, Syria .Vol.4, 25pp.

Mohamed, F.E. and Amer M.A. (1965) . Oils, Fat, Waxes and Surfactants .Anglo. Egyptian Book Shop .publishers .Cairo, U.A.R., pp. 259.

Nawwar M.A., Ayoub N.A., El Rai M.A., Bassyouny F., Mustafa E.S., Al-Abd A.M., Harms M., Wende K., Lindequist U. and Linscheid M.W. (2012). Cytotoxic ellagitannins from Reaumaria vermiculata. Fitoterapia, 83 (7): 12561266.

Nelson J.P., Milim A.J. and Fister H.D. (1969). Gas chromatographic determination of tocopherols and sterols in soya sludge's and residues an improved method. JAOCS, 47: 259-261.

Pellet P.L. and Young V.R. (1980). Nutritional evaluation of protein foods. Published by the United Nation Univ.

Polterait O. (1997). Antioxidants and freeradical scavengers of natural origin. Current Org. Chem., 1: 415-440.

Pulido R., Bravo L. and Saura-Calixto F. (2000). Antioxidant activity of dietary polyphenols as determined by a modified ferric reducing antioxidant power assay. J. Agric. Food Chem. 48: 3396-3402.

Rowell D.l. (1994). In "Soil Science - Methods and Application . Longman publishers , Singapore, 350pp.

Tackholm ,V. (1974). In " Student Flora of Egypt ". II Edition. PP, 888. Published by Cairo Univ. Egypt.

Wall N.F., Kreider M.M., Kremson C.F., Eddy C.R. Williaman J.J., Corell D.S. and Gentry H.S. (1954). Steroidal sapognins and other constituents. J.Pharm. Soc., 43: 1-3.

Woo W.S., Chi H.J. and Yun H.S. (1977). Alkaloid screening of some Saudi Arabian plants Kort. J. Pharmacognosy, 8(3): 109113.

Yoshida T., Ahmed A.F., Memon M.U. and Okuda T. (1991). Tannins of Tamaricaceous plants II. New monomeric and dimeric hydrolysable tannins from Reaumuria hirtellla and Tamarix pakistanica. Chem. Pharm. Bull., 39: 2849-2854.

Yoshida T., Ahmed A.F. and Okuda T. (1993). Tannins of Tamaricaceous plants III. New dimeric hydrolysable tannins from Reaumuria hirtellla. Chem. Pharmco. Bull., 41: 672-679.

Zahra A.M.K. (1990). Studies on wilt disease of seasame (Seasamum indicum L.) in Upper Egypt. Ph.D. Thesis, Fac. Agric., Assiut Univ., p. 118. 
ـ تقدير الفلافونيدات و الفينو لات و القلويدات و التنانينات خلال فصول السنة الأربعة.

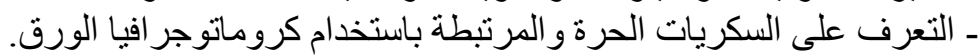

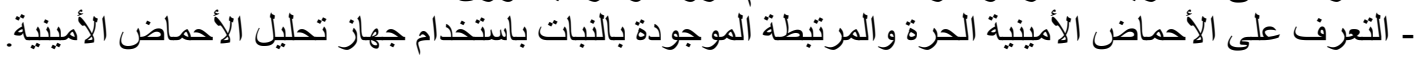

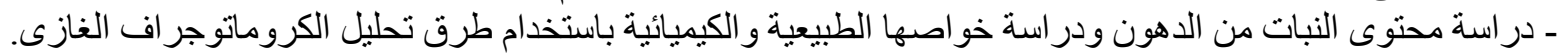

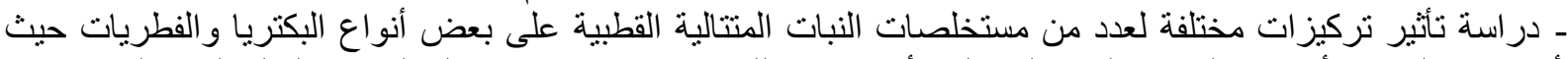

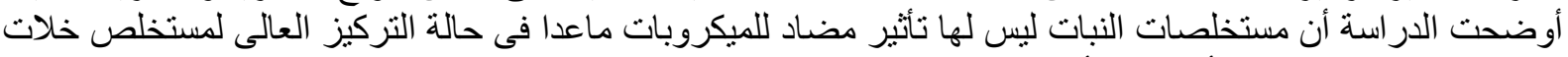

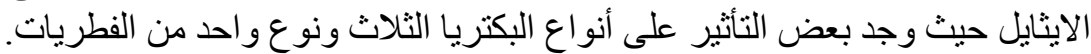

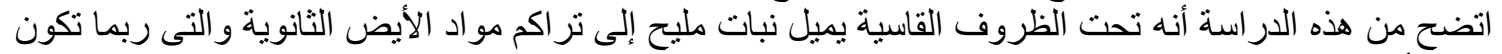

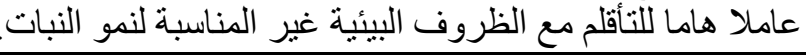

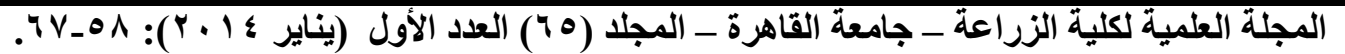

